\title{
Host-Children of Tourism Destinations: Systematic Quantitative Literature Review
}

\author{
Mona Ji Hyun Yanga*; Elaine Chiao-Ling Yang ${ }^{\mathrm{b}}$ and Catheryn Khoo- \\ Lattimore $^{\mathrm{c}}$
}

${ }^{a}$ PhD Candidate, Department of Tourism, Sports and Hotel Management, Griffith

University, Brisbane, Australia, ORCiD: http://orcid.org/0000-0002-4049-7344

${ }^{b}$ Lecturer, Department of Tourism. Sports and Hotel Management, Griffith University, Brisbane Australia, ORCiD: https://orcid.org/0000-0001-5245-1688

${ }^{c}$ Senior Lecturer, Department of Tourism and Hotel Management. Griffith University, Brisbane, Australia, ORCiD: http://orcid.org/0000-0003-2858-870X

* Corresponding author's e-mail: monajihyun.yang@griffithuni.edu.au

Ms Mona Ji Hyun Yang:

Ms. Mona Yang is a Doctoral candidate in Tourism, Hotel and Sports Management at Griffith University. She holds a degree of Bachelor of Business with Honours in International Tourism from Griffith University. Mona's research interest is children, particularly from Asian perspectives. She has co-published two journal articles on Malaysian-Chinese and European family holidays in Young Consumer and Journal of China Tourism Research. In addition, Mona presented at the renowned international tourism conference, CAUTHE 2016. Currently, for her doctoral thesis, she is exploring the quality of life of children in host-countries.

Dr Elaine Chiao-Ling Yang

Dr Elaine Yang is a Lecturer in the Department of Tourism, Sport and Hotel Management, Griffith University. Elaine's research interest is in Asian tourism, gender, solo consumer and tourist risk perception. Elaine has co-published two edited books on Asian tourism. Her works have also been published in Tourism Management, Journal of Travel Research and Current Issues in Tourism. Elaine is an editorial board member of Tourism Management Perspectives and Annals of Leisure Research. Elaine has been identified as an Emerging Tourism Scholar by e-Review of Tourism Research. She is a proud volunteer administrator of Women Academics in Tourism (WAiT). 


\section{Dr Catheryn Khoo-Lattimore}

Dr. Catheryn Khoo-Lattimore is a Senior Lecturer in the Department of Tourism, Sport and Hotel Management, Griffith University. Catheryn's current research interest is in tourist and guest behaviour, with a passionate focus on women, families and young children. She is also particularly interested in understanding these segments from an Asian perspective, and how Asian tourists' travel experience and behaviours differ cross-culturally. Catheryn is Editor-in-Chief of Tourism Management Perspectives and serves on the editorial boards of several other tourism and hospitality journals. She is Second Vice-Chair of the Council for Australasian Tourism and Hospitality Education (CAUTHE). She is also the founder and chair of Women Academics in Tourism (WAiT). 


\section{Host-Children of Tourism Destinations:}

5 Abstract:

6 Although it is estimated that 19 million children are engaged in the tourism industry, our

7 knowledge of child labour issues within tourism is highly limited. This paper systematically

8 and quantitatively reviewed interdisciplinary research on host-children, aiming to identify the

9 extent of scholarly attention. The work sought to map the trajectory of existing literature and

10 identify whether, and if so, how host-children were included in research. The review revealed

11 that within the limited host-children studies, child sex workers have received the most attention

12 whereas issues relating to other child labourers have been neglected. Additionally, this review

13 identified that the subjective dimensions of tourism impacts on host-children have been

14 overlooked and limited studies have actually reflected children's voice in the research. Based

15 on these findings, the directions for future research on host-children are recommended.

16 Key words: Host-children; Child Labourers; Children in Tourism; Children's perspective;

17 Children's voice; Systematic Quantitative Literature Review 


\section{Introduction}

Globally, one in ten children works in a mentally, physically, socially and morally dangerous environment (International Labour Organization [ILO], 2017). This represents 152 million children worldwide (5-17 years old). The actual number of child labourers in tourism is not available and an accurate estimation is almost impossible because of those who are hidden away from the public and are therefore invisible — for example, children washing dishes behind closed doors or working as illegal sex workers (Hagedoorn, 2013). Nevertheless, child labour is present in the tourism industry where children are commonly engaged as workers and/or social actors in souvenir and hospitality businesses, cultural performances, and orphanages (e.g., voluntourism), especially in developing countries (ILO, 2002). It is estimated that about 19 million workers $(15 \%)$ in tourism and hospitality industries are children (ILO, 2002), and they are particularly vulnerable in the tourism and hospitality industries where in general working hours are long, jobs are insecure, wages are low, and labour laws are often infringed (Hagedoorn, 2013). Child labourers might not have opportunities to access training and some might even have to forego education for work (Hagedoorn, 2013). Despite the vulnerability of children working in the tourism industry, child labour in tourism remains an under-researched area (Bakas, 2018).

The lack of tourism research on child labour pertains to a dearth of attention paid to children more broadly in tourism research (Canosa, Moyle, \& Wray, 2016; Poria \& Timothy, 2014). Although the definitions of child vary by contexts and cultures (Canosa et al., 2016; Morrow, 2011), this paper uses the definition of a child based on the United Nation Convention on the Rights of the Child (1989), which refers to 'a person under the age of 18 years' (The United Nations, 2010, p. 1). Within the handful of studies on children in tourism, Canosa et al. 41 (2016) observed that less attention has been paid to children living in tourist destinations. To 
studies published in tourism journals, where children were categorised as either those who are tourists (hereafter tourist-children) or those who live and work in tourist destinations (hereafter host-children). The preliminary review indicated that the existing tourism research on children has mainly addressed tourist-children relating to their holiday experience (e.g., Gram, 2005; Nickerson \& Jurowski, 2001), motivation for visiting tourist destinations (e.g., Allan, 2014), and family holidays with children (e.g., Backer \& Schänzel, 2013; Khoo-Lattimore, delChiappa, \& Yang, 2018; Khoo-Lattimore, Prayag, \& Cheah, 2015). On the contrary, minimal research has addressed host-children in the tourism context.

Given the scant attention paid to host-children in tourism, this paper aims to systematically review and map the landscape of host-children in the interdisciplinary literature and identify the knowledge gaps by addressing three main research questions: (1) How, and to what extent has existing literature paid attention to children at host destinations?; (2) What is the trajectory of host-children research in terms of disciplines, themes, theoretical frameworks and geographical locations?; (3) How, and to what extent have children's voices been reflected in the existing literature?

The significance of this review is threefold: First, reviewing existing literature on hostchildren would reveal the circumstances and conditions of children living in host communities. Within the neoliberalist context, tourism inevitably causes inequality by exploiting host communities, particularly in the developing world (Higgins-Desbiolles, 2006; Wearing, 2002). However, tourism has also been said to have a transformative capacity as a social force that gives meaning to people and places and improves individuals' wellbeing (Dredge et al., 2012; Higgins-Desbiolles, 2006). This review will provide an objective analysis on the impacts of tourism, both positive and negative, on children living in host communities. Second, building on the narrative review of Canosa et al. (2016) on host-children, this paper visualises the absence of host-children by systematically and quantitatively analysing host-children studies. 
68 A systematic literature review is transparent in the literature search, extraction and analysis, allowing for scholarly inspection of credibility and trustworthiness (Yang, 2017). Unlike the traditional narrative literature review which focuses on a specific theoretical framework, the outcomes of the Systematic Quantitative Literature Review (SQLR) are expected to identify patterns, knowledge gaps and provide directions for future research on host-children. Third, this paper looks beyond the field of tourism to provide a comprehensive and interdisciplinary understanding of host-children, therefore extending Canosa et al. (2016)'s review, which was limited to the tourism and anthropological disciplines. This paper will widen the results of this previous host-children review and shed light on host-children from broader disciplinary perspectives.

\section{Methodology}

\subsection{Systematic Quantitative Literature Review (SQLR)}

Literature review can be broadly categorised into three different approaches including meta-analysis, the traditional narrative review, and the SQLR (Pickering \& Byrne, 2014). Different types of literature reviews generate different understandings in building knowledge and writing texts (Pickering \& Byrne, 2014). Meta-analysis review aims to combine and synthesise the results of other studies in any other contexts (Mays, Pope \& Popay, 2005). Traditional narrative literature review is a comprehensive way to bring together fragmented knowledge focusing on theoretical frameworks from the representative literature selected by the author's own judgement (Pickering \& Byrne, 2014). On the other hand, SQLR is a method emphasising a transparent and systematic process to the literature search, extraction and synthesis (Yang, Khoo-Lattimore \& Arcodia, 2017). SQLR provides a comprehensive and systematic structure for identifying and plotting the borders of the existing research by enumerating the number and proportion of studies according to the review aims and questions (Healey \& Healey, 2010; Petticrew, 2001; Pickering \& Byrne, 2014). SQLR is instrumental in 
93 demonstrating thematic, methodological and geographical gaps, and in synthesising a 94 heterogeneous collection of interdisciplinary research from different settings (Pickering \& Byrne, 2014). In addition, SQLR has fewer biases in identifying gaps compared to traditional narrative literature reviews (Pickering \& Byrne, 2014). Given the advantages, SQLR has received increasing attention in tourism research (Khoo-Lattimore, Mura, \& Yung, 2017; Kim, Bai, Kim, \& Chon, 2018; Yang, Khoo-Lattimore, \& Arcodia, 2017; Yung \& Khoo-Lattimore, 2017).

Since the primary purpose of this paper is to map the landscape of host-children in the

101 interdisciplinary literature and to identify the boundary of knowledge, the SQLR method is adopted. To identify host-children studies, an iterative database search was commenced on the $2^{\text {nd }}$ July 2018 using the following search terms: ("Child*” OR "Adolescent") AND ("Tourism" OR "Hospitality"). To ensure comprehensiveness, the search was conducted on five databases including Scopus, EBSCO Host (Hospitality and Tourism Complete), Science Direct (Elsevier),

106 Emerald, and ProQuest (Yang et al., 2017; Yung \& Khoo-Lattimore, 2017). Using the database 107 search function, the search was limited to the titles, keywords and abstracts. To gather the interdisciplinary literature beyond the tourism and anthropological disciplines, the subject areas were filtered to include 'social science', 'business, management and accounting' 'law',

110 'arts and humanities' and 'agricultural and biological science'. Publications from medical 111 journals were excluded as children were investigated from a pathological and medical 112 perspective. Document types were constrained to English language, peer reviewed journal 113 articles and book chapters with full text access, excluding conference papers and books. The 114 exclusion was mainly based on the criterion of peer-review for the purpose of quality and 115 credibility (Pickering \& Byrne, 2014). No date range was set to the search, which means any 116 publications that fulfilled the search criteria would be identified regardless of the publication 117 year. In total, 973 articles were identified. Figure 1 provides the modified Preferred Reporting 
118 Items for Systematic Reviews and Meta-Analysis (PRISMA) flowchart (Moher, Liberati,

119 Tetzlaff, Altman, \& Group, 2009) for this review.

The studies were exported to Endnote to identify and remove duplicates. The titles and abstracts of the remaining 829 articles were assessed and 563 studies were eliminated according to two selection criteria. First, this review excluded all studies that were not directly related to

124 host-children and tourism, such as reproductive tourism (e.g., Buchitchon, 2016; Bylth \& 125 Farrand, 2005; Harrison, 2014), organ transplantation tourism (e.g., Muto, 2010), and marriage 126 tourism (e.g., Soliman, Alsharqawi, \& Younis, 2018). Studies on immigration (e.g., Barakat127 Haddad \& Dghaim, 2015) and refugees (e.g., Perumal, 2013; Wang, 2014) were also excluded 128 as they addressed a wider mobility issue rather than the conventional tourism, which is mainly 129 leisure-based. Additionally, all studies with a focus on child sex exploitation were deleted 130 unless they primarily addressed child sex tourism. For example, an article by Levesque (1995) 131 was excluded as it mainly examined international law regarding child sexual maltreatment. In the article, sex tourism was briefly mentioned as an example of child sex crime, but the article mainly focused on regulations to combat child sexual exploitation. Secondly, any studies that

134 could not be sorted clearly into tourist-children or host-children were excluded because the 135 purpose of this paper is to review host-children studies. For example, research exploring 136 student-children studying in tourism and hospitality schools (e.g., Muñoz-Fernández, 137 Rodríguez-Gutiérrez, \& Santos-Roldán, 2016; Newnham, 2007; Puharić, Slijepčević, Badrov, 138 \& Petričević, 2016) and those addressing the difficulties of researching children in general (e.g., 139 Canosa \& Graham, 2016) were removed.

140 An additional screening was added to the original PRISMA flowchart (see shaded boxes in Figure 1) where the remaining 266 studies were categorised into either 'host-children' 
142 or 'tourist-children'. The screening results revealed that 80 studies researched 'host-children'

143 while 186 studies focused on 'tourist-children'. This result will be discussed in the findings

144 section. The full texts of the 80 host-children studies were obtained for further analysis using

145 Microsoft Excel. After assessing the full papers of the 80 studies, 10 were eliminated because

146 the papers did not actually explore children in the tourism context, even though the terms,

147 'children' and 'tourism' were mentioned in the abstracts (e.g., Eades, 2007; Llorca-Rodríguez,

148 Casas-Jurado, \& García-Fernández, 2016). For instance, Bocij and McFarlane (2003) referred

149 to virtual child sex tourism, which was defined as child pornography inflicting sexual

150 maltreatment on children from a distance. This study was excluded as the reference to 'tourism'

151 was purely metaphorical. Consequently, only 70 studies were eligible for the review.

The bibliographic details of the 70 studies were tabulated in Microsoft Excel. Given

that this paper sought to identify the disciplines, theoretical frameworks and geographical locations of existing host-children studies, information regarding journals, theories, and host countries were recorded in the table. Furthermore, this review also aimed to identify the representation of host-children's voices. Information pertaining to how and from whom the data were collected and whether the research explicitly considered ethical issues to include host-children was recorded in the table. The summarised table was analysed using content analysis to quantify the patterns and identify the research gaps.

\subsection{Leximancer Conceptual Map}

To identify the main research themes across the 70 studies, a conceptual map was generated using Leximancer software, which provides machine-generated content analysis based on the properties of texts (Sotiriadou, Brouwers, \& Le, 2014). This system is useful as it

164 reduces the risk of human errors and greatly improves time and cost efficiency (Smith \&

165 Humphreys, 2006). However, Leximancer has been criticised because it still requires the researchers to interpret the conceptual map (Hansson, Carey, \& Kjartansson, 2010), and the 
generated map may contain unexplained concepts and relationships (Sotiriadou et al., 2014).

168 Despite these limitations, Leximancer has been used in several tourism studies (e.g., Tseng,

169 Wu, Morrison, Zhang, \& Chen, 2015; Wu, Wall, \& Pearce, 2014) as the machine-generated

170 conceptual map is instrumental in demonstrating dominant themes and related concepts and in

171 reducing bias in the coding process (Sotiriadou et al., 2014). Additionally, given that

172 Leximancer generates a conceptual map by quantifying the results of qualitative analysis

173 (Indulska, Hovorka, \& Recker, 2012; Tseng et al., 2015), Leximancer is suitable for this SQLR

174 paper which aims to systematically quantify the themes of host-children studies.

To generate a conceptual map, the titles and abstracts of the 70 studies were imported into Leximancer. In determining the concept seeds, terms such as 'article', 'study', 'paper', 'approach', 'research', 'use', 'including', 'implication' and 'used' were removed because these words could distract the software from creating accurate themes. Synonyms or variations of words (e.g. 'child and children' and 'economic and economy') were merged because although

180 these words are in different forms, they shared the same meaning. As a result, three main themes were generated and they were labelled as Child Labourer, Child-Resident and Voluntourism. The reliability of the generated conceptual map and the frequency of studies in each theme were triangulated by manually categorising the 70 studies according to the three themes. These findings will be discussed in 3.2. Themes of Host-Children Studies.

\section{Findings}

During the screening process, it was identified that among the 266 studies addressing children in tourism, 186 studies (or approximately 70\%) studied tourist-children, while only 80 studies (about 30\%) paid attention to host-children (see the shaded boxes in Figure 1). These figures lend support to the argument of Canosa et al. (2016), showing that far less attention has been paid to host- than tourist-children. Considering the lack of attention, this review mapped

191 the trajectory of host-children research and analysed past studies conducted on host-children. 


\subsection{Disciplines of Host-Children Literature}

To identify which fields or disciplines have considered host-children, the publication outlets of the studies were analysed. Of the 70 studies, three were book chapters and they were in the tourism (e.g., Beddoe, 2003), sociology (e.g., Tepelus, 2006) and ethnographic (e.g.,

196 Dewey \& Conver, 2012) disciplines. After eliminating the two book chapters, 67 journal

197 articles were analysed and interestingly, as many as 58 different journals were recorded. Table 1 presents a list of the top seven journals which have published the greatest number of studies. Each of the seven journals has published two or three articles while the remaining 51 journals have published only one article on host-children. This indicates that host-children is a marginalised topic which has received minimal attention across the disciplines. Table 1 also shows that host-children have received attention from not only tourism journals but also human rights, sexuality and law journals such as American Journal of Human Biology, International Journal of Children's Rights and St. John's Law Review.

[Table 1 near here]

One third of the articles were published in tourism journals, and tourism journals made up a quarter of all the journals that have published works on host-children. Table 2 is a list of 18 tourism and hospitality journals, which have published 24 articles in total. The remaining 43 studies were published in 40 other non-tourism journals. This finding implies that hostchildren have not received substantial attention in the tourism discipline.

\subsection{Themes of Host-Children Studies}

A conceptual map comprising three themes was generated using Leximancer - Child

214 Labourer, Child-Resident and Voluntourism (see Figure 2). The conceptual map shows that

215 Child Labourer is the main theme comprising studies exploring children working in the 
216 tourism-related industries. The theme evolves around machine-generated concepts such as

217 'sex', 'policy' and 'industry'. Child-Resident is a theme consisting of studies that investigated

218 the impacts of tourism on the residents, encompassing adults and children in the communities.

219 The theme includes concepts such as 'social', 'community', 'local' and 'development'.

220 Voluntourism covers the concepts of 'tourists' and 'volunteer', encompassing research that

221 focused on voluntary activities aiding host-children in the tourism context.

[Figure 2 near here]

Conceptual maps generated by Leximancer does not offer an accurate number of studies in each theme (Wu et al., 2014). To overcome this issue, manual counting of the numbers of studies in each theme was conducted (refer to Table 3). One study (i.e., Johnson, 2014) was found to be related to multiple themes, Child Labourer and Voluntourism. Johnson (2014) addressed the violation of Asian children's rights in the tourism context through the practice of child labour and orphanage tourism. As such, it was counted in both Child Labourer and Voluntourism. Two studies did not fit into any theme: One reviewed the role host-children in literature (e.g., Canosa et al., 2016) and the other was about training local Brazilian children in an ecotourism program (e.g., Pegas, Coghlan, \& Rocha, 2012). Despite these exceptions, the results of the manual coding (Table 3) were consistent with the conceptual map (Figure 2), confirming the reliability of Leximancer in generating conceptual maps.

Out of 40 studies in the Child Labourer theme, 35 studies investigated child sex workers. Most of these studies focused on combatting child sex tourism (e.g., Leung, 2003), the spread of HIV/AIDS (e.g., Chheang, 2008), and the social responsibility of tourism corporations to combat child sex tourism (e.g., Härkönen, Linköpings, Affärsrätt, \& Filosofiska, 2016; Tepelus, 2008). Only five studies in the Child Labourer theme investigated general child labourers 
outside the sex tourism context. Al-Frehat and Alhelalat (2015) and Magablih and Naamneh

241 (2010) explored the causes and consequences of child labour in the tourism industry. Bakas

242 (2018) studied the political-economic roles of children working in family tourism businesses

243 and how their economic activities influenced their parents gendered entrepreneurial roles.

244 Similarly, Monterrubio, Rodríguez-Muñoz, and Durán-Barrios (2016) investigated how the

245 engagement of children labourers in tourism preserved traditional gender roles.

In Child-Resident, which is the second biggest theme, several studies investigated how host-children perceived or made sense of tourism spaces (e.g., Buzinde \& Manuel-Navarrete, 2013; Ohashi et al., 2012), tourists and also themselves as residents living in the host communities (e.g., Canosa et al., 2016; Gamradt, 1995; Molero, Navas, Alema’ n, \& Cuadrado, 2003). Other studies investigated the impact of economic development and modernisation driven by the tourism industry on host-children's health (e.g., Dancause et al., 2011; Himmelgreen, Romero-Daza, Amador, \& Pace, 2012; Leatherman, Goodman, \& Stillman, 2010; Pollard et al., 2000) and on street children's access to education (e.g., Gössling, Schumacher, Morelle, Berger, \& Heck, 2004). Several studies explored the impacts of tourism on host-children with a focus on material and health impacts; no study considered the quality of life or well-being of the host-children despite the transformative potential of tourism if channelled into the right directions (Higgins-Desbiolles, 2006).

Voluntourism refers to holidays that aid or alleviate the material poverty of certain communities (Proyrungroj, 2017). As far as children are concerned, voluntourism is often associated with orphan tourism, which refers to a temporary volunteer trip to visit orphanages (Carpenter, 2015). Orphan tourism is one of the most popular activities among volunteer tourists due to the opportunity to interact with children (Carpenter, 2015). As a result of the growing popularity of voluntourism (Proyrungroj, 2017), it has received increasing scholarly attention. Past studies have investigated volunteer tourists' experiences and motivations (e.g., 
265 Carpenter, 2015; Freidus, 2017; Proyrungroj, 2017; Rotabi, Roby, \& McCreery Bunkers, 2016;

266 Tomazos \& Butler, 2012); cultural confrontation between tourists and host-children (e.g.,

267 Klaver, 2015); commodification of host-children (e.g., Guiney, 2018; Reas, 2015); the channel

268 of voluntourism and tourists' perception of the impacts of voluntourism (e.g., Rogerson \&

269 Slater, 2014); political activities such as anti-orphanage tourism campaigns (e.g., Guiney \&

270 Mostafanezhad, 2015); and improvement of voluntourism with regards to the risks facing both

271 tourists and children (e.g., Wilson, 2015). Most studies exploring voluntourism come mainly

272 from tourists' and political perspectives; no study has investigated voluntourism from

273 children's perspectives.

274

275

276

277

278

279

280

281

282

283

284

285

\subsection{Theoretical Framework}

The theoretical frameworks in the 70 studies were reviewed. We considered theoretical frameworks not only in deductive (where a theory is identified a priori) but also in inductive papers (where the theoretical constructs emerged from the findings) and literature reviews (where theoretical framework is created). We only paid attention to those papers that explicitly named the theories they utilised (deductive) or conceptualised (inductive). Table 4 summarised the theoretical frameworks/concepts that were utilised to investigate each theme, and the foci and field/disciplines of the studies where theories were used. In terms of field/disciplines, of the 13 , seven were in the tourism and hospitality filed while the others are in sociology, geography and politics.

In Child Labourer, six studies explicitly engaged in theoretical discussions when investigating issues related to child sex workers. Corporate Social Responsibility (CSR) was adopted by three studies (e.g, Kalargyrou \& Woods, 2015; Tepelus, 2006, 2008) while other theoretical frameworks/concepts, including In-group Bias (e.g., Kosuri \& Jeglic, 2017), Orientalism and Concepts of Power (e.g., Bandyopadhyay, 2012), and Biological Systems (e.g., Spurrier \& Alpaslan, 2017) were adopted once. Among studies that explored general child 
290 labourers, only Bakas (2018) overtly engaged in theoretical discussion in which Critical

291 Feminism was employed as the theoretical lens. In Child-Resident, only one study clearly

292 declared the theoretical underpinning, which is Transformation of the Self (e.g., Gamradt, 293 1995). In Voluntourism, Emotional Labour (e.g., Guiney, 2018), Hofstede's Individualism (e.g.,

294 Klaver, 2015), Double Movement (e.g., Guiney \& Mostafanezhad, 2015), Symbolic Violence,

295 Civilised Oppression and Abuse in the Benign (e.g., Reas, 2015), and Altruistic exploitation 296 (e.g., Rotabi et al., 2016) were adopted.

\section{[Table 4 near here]}

\subsection{Host Countries}

Figure 3 presents the geographical distribution of the host destinations that were covered in the 70 studies. In the map, the darker colours indicate higher frequency (i.e., more studies being studied in that region). The pie charts show the proportion of the research themes conducted in each region. A further analysis was conducted on Child Labourer to identify the extent of attention given to general child labour as opposed to child sex worker in each region.

According to ILO (2002), child labourers were mainly located in the Asia/Pacific region and Sub Saharan Africa. The findings are partially in line with the geographical distribution suggested by ILO. As illustrated in Figure 3, most of the studies have focused on South Asia and South East Asia, followed by Central America. Africa, however, has received minimal scholarly attention. Likewise, other regions might have host-children issues unique to the local context, but this assumption is not substantiated due to the lack of research. Within the handful

311 of studies on Africa, a few explored child sex workers while no study has explored general 
313 more than other regions, most studies investigated child sex workers and no study investigated

314 the general child labourers.

\section{$315 \quad 3.5 \quad$ Children's Involvement}

316 Prior studies (Canosa et al., 2016; Poria \& Timothy, 2014) argue that there are few host-

317 children studies and fewer of these reflect children's voices. One of the aims of this review was

318 to identify whether host-children voices are reflected in multi-disciplinary literature and if so,

319 how the studies involve children in data collection. To analyse host-children's voices, the

320 following three sub-sections will report on how many studies used empirical data, then how

321 many empirical studies actually involved children and finally, how the researchers actually

322 engaged with children in research.

323

324

325

326

327

328

329

330

331

\subsubsection{Empirical Data}

Among the 70 papers, fewer than half (34 studies), collected empirical data. Figure 4 compares the number of empirical and non-empirical studies by research themes. The lack of empirical research is especially prominent in Child Labourer, with only $27 \%$ of studies had collected empirical data. Deficiency of empirical data in child labourer studies could be attributed to the sensitivity and inaccessibility of child sex workers. Given the challenges, a number of child sex worker studies relied on secondary data such as ratification (e.g., Alexander, Meuwese, \& Wolthuis, 2000), policies and regulation (e.g., Johnson, 2011), and jurisdiction (e.g., Hogan, 2007). These can be insightful in terms of informing how politicians and judicial professions have strived to combat child sex tourism. However, the lack of primary data in these studies is problematic because perspectives from those who would be potentially impacted by the policies and/or ratification - the children - have not been taken into conditions. Therefore, knowledge regarding the feasibility of current enforcement on children themselves needs to be developed, from the children's perspectives. 


\subsubsection{Children's Voices}

Prior studies (Canosa \& Graham, 2016; Powell et al., 2018) argued that it is important to access the voices of children involved in child labour, child sex tourism and orphanage tourism. Table 5 is a summary of how children's voices were considered in the 34 empirical studies, according to the three research themes. Across the themes, Table 5 shows that only 19 out of 34 studies reflected children's voices.

\section{[Table 5 near here]}

The Child Labourer theme consists of 11 empirical studies but more than half of which did not include children's voices. For instance, Bakas (2018) investigated children's role as economic actors by interviewing their parents. The parents might be able to somewhat explain their children's entrepreneurial experiences, but the children themselves might provide insights that are different from those assumed by their parents (Canosa \& Graham, 2016; KhooLattimore, 2015; Poria \& Timothy, 2014). Given these reasons, involving children is crucial to gain accurate information. Despite the value of children's voices, only five studies involved children's voices. Three studies collected data from only children (e.g., Al-Frehat \& Alhelalat, 2015; Monterrubio et al., 2016; Montgomery, 2008) and two studies overcome the methodological challenges of researching children by involving children with their guardians (e.g., Magablih \& Naamneh, 2010), Government and Non-Government Organisations (NGO) (e.g., Miller, 2011) in the research process.

Contrastingly, all studies in the Child-Resident theme involved children, except for two studies (e.g., Agyeiwaah, Akyeampong, Boakye, \& Adu-Gyamfi, 2014; Sinervo \& Hill, 2011). The higher rate of involving children in research can be explained by the topics in the ChildResident theme. Since many studies explored the impact of tourism on host-children's health 
361 (e.g., Anderson-Fye, 2004; Dancause et al., 2011; Leatherman et al., 2010) and their perception

362 of tourism spaces (e.g., Buzinde \& Manuel-Navarrete, 2013; Ohashi et al., 2012), tourists (e.g.,

363 Canosa, Wilson, \& Graham, 2017; Molero et al., 2003) and themselves (e.g., Gamradt, 1995),

364 it was necessary for researchers to collect data from children.

365 In contrast, most studies in the Voluntourism theme did not involve children due to the 366 foci of the investigation. As a majority of the studies explored the voluntourism experiences of 367 tourists (e.g., Proyrungroj, 2017; Tomazos \& Butler, 2012) and the political conflicts of 368 voluntourism (e.g., Guiney, 2018; Guiney \& Mostafanezhad, 2015), children were not engaged 369 in the studies. Only Klaver (2015) involved children to explore conflicts between tourists from 370 individualist countries (e.g., USA and Netherlands) and children in Guatemala, which is a collectivist society.

Prior research has cautioned the ethical issues of involving children in research (Canosa \& Graham, 2016; Khoo-Lattimore, 2015; Poria \& Timothy, 2014). Nevertheless, among 19 studies involving children across the three themes, only nine studies explicitly addressed the ethical issues. Nonetheless, most studies addressing ethical issues mentioned briefly that children's guardian's consents were collected, whereases only Monterrubio et al. (2016) substantially addressed the ethical issues by ensuring the children are protected from any risks

378 presented in the research, paying attention to instrument design, and getting consents from both

379 children and their guardians. Additionally, Monterrubio et al. (2016) addressed the disparities in power between researchers and children by using non-invasive, non-confrontational and

381 participatory approach.

\subsubsection{Research Methods}

Given that one of the aims of this review was to explore how existing literature reflects 
Table 6 illustrates the research techniques that were used to collect data from children; data collection involved adult participants were omitted.

\section{[Table 6 near here]}

Across the three themes, qualitative methods were used more frequently to reflect children's voices. In particular, ethnography and visual methods were the most prevalent techniques to involve children. A few scholars used ethnography to investigate child sex workers (e.g., Miller, 2011; Montgomery, 2008) and general child labourers (e.g., Monterrubio et al., 2016), and to interpret the impact of tourism on children's perception of tourism space (e.g., Cross, 2006; Tirasattayapitak, Chaiyasain, \& Beeton, 2015) and the impact of the image of poor children on the destination images (e.g., Sinervo \& Hill, 2011).

Five studies adopted visual methods such as drawings, photographs and participatory films to gain in-depth data from children. Drawings appear to be the most popular visual method to understand children's participation in tourism labour (e.g., Monterrubio et al., 2016), children's perception of tourist spaces (e.g., Buzinde \& Manuel-Navarrete, 2013) and hostchildren's understanding of tourists, tourism and themselves (e.g., Gamradt, 1995). Canosa et al. (2017) and Ohashi et al. (2012) had children create animations and videos respectively to understand how they perceive tourism in their communities.

Seven studies used quantitative methods including surveys and tests. Four studies used tests to measure the impact of tourism on the health of children (e.g., Jensen, Marlin, Dyck, \& Laubach, 2009; Leatherman et al., 2010; Pollard et al., 2000) and to measure the internal disposition of children (e.g., Klaver, 2015). Three studies conducted surveys to identify child labourers' education status (e.g., Al-Frehat \& Alhelalat, 2015), to examine the feasibility of malaria eradication programs (e.g., Dancause et al., 2011), and to evaluate children's perception of tourists and immigrants (e.g., Molero et al., 2003). Most studies did not explicitly 
409 describe how they considered children in their design instruments with only one exception.

410 Given the children's vulnerability, Molero et al. (2003) paid attention to questionnaire design

411 by carefully selecting adjectives used for the scale. For example, they avoided using highly

412 negative adjectives to describe the negative pole of the scale to avoid affect susceptibilities of

413 children.

\section{$414 \quad 4 . \quad$ Discussions}

This study systematically reviewed the interdisciplinary literature with an aim to map and identify the knowledge gaps related to host-children. This SQLR study systematically and quantitatively supports some of Canosa et al.’s (2016) arguments, but also reveals new insights. Canosa et al. (2016) critically analysed the role of host-children in the tourism literature by categorising the framework and examining the presence and role of indigenous people in tourism research. Canosa et al. (2016) identified the lack of host-children's agency and engagement in research, and called for child-driven research with voice-generative methods. The findings of this SQLR provides evidence to the arguments that host-children have not received substantial scholarly attention. This SQLR not only extends the work of Canosa et al. (2016), but also brings together fragmented existing knowledge and provides new insights by systematically and quantitatively analysing the interdisciplinary literature and identified research themes. Table 7 presents a summary of the key insights and directions for future research, built on the findings of this review. The insights and directions for future research are discussed in this section.

\section{[Table 7 near here]}

\subsection{Paucity of Host-Children Research in Interdisciplinary Literature}

Although host-children refers to the children living in the tourist destination, the topic of 'host-children' has a highly interdisciplinary nature. It was evident in the analysis of journals, 
433 demonstrating many non-related tourism journals published articles on host-children in the

434 tourism context. Despite the interdisciplinary nature, it was identified that host-children have

435 received relatively less attention in research compared to tourist-children. The reason for this

436 limited attention to host-children pertains to the tendency for stakeholders in tourism

437 businesses to perceive children as having no commercial value (Canosa \& Graham, 2016).

438 Given this tendency, host-children have received far less attention than tourist-children

439 regardless of discipline. However, tourism is not just an industry but also a social force with

440 transformative and disruptive power over host-communities (Higgins-Desbiolles, 2006).

441 Hence, it is highly necessary to consider the social capacity tourism has and explore host-

442 children from a broader perspective rather than just the economic aspect.

The review on host-children also found that many studies lack theoretical

frameworks/concepts regardless of discipline. This may be related to the tendency of tourism research being dominated by policy and industry-led foci (Franklin \& Crang, 2001) and the high number of non-empirical studies without sound theoretical underpinning. Additionally, this finding is in line with the lack of tourism theories in general (Franklin \& Crang, 2001), which trickles down to the lack of available theoretical underpinning to investigate children in the tourism context (Poria \& Timothy, 2014). Future research on host-children is encouraged to focus on theoretical development in order to break new conceptual and/or ethical grounds.

\subsection{Child Labour Studies: Skewed Focus}

This SQLR has drawn a trajectory of the existing literature on host-children by identifying the themes using Leximancer, and identified Child Labourer as the biggest theme in host-children research. However, in Child Labourer, most studies have explored child sex workers with only a handful of studies exploring general child workers.. This skewed attention to child sex workers is because law-, human rights- and sexuality-related fields/disciplines have an interest in child sex tourism, as it is a social issue violating children's rights and spreading 
HIV/AIDS. However, research on general child labourers is necessary because of the presence of children working in the tourism industry where the working environment is risky and unprotected due to ineffective labour laws and long working hours (Hagedoorn, 2013). Furthermore, many child labourers are working behind closed doors washing dishes and making souvenirs - they are the 'hidden' labourers (Hagedoorn, 2013). It is hard to estimate

463 how many hidden child labourers there are in tourism and therefore it is difficult to protect them. This review found that some studies investigated child labourers in Africa and Asia but again, they predominantly focused on child sex workers with little to no attention paid to general child labourers, despite these two regions being identified as having the most child labour issues (ILO, 2002). Therefore, interdisciplinary scholarship is recommended to deepen existing knowledge on general child labour issues in the Asian and African regions.

\subsection{Impacts of Tourism: External vs Internal}

Within the limited research on host-children, far less attention was paid to individuals' lives as host-children, although children are particularly vulnerable to the impacts of tourism

472 (Vanclay, 2003). Some studies on host-children explored the impact of tourism on children's attitudes, perception of tourism, and objective wellbeing related to economic, social and political issues, but subjective dimension such as children's perception of happiness and life satisfaction as hosts were neglected. (Andereck \& Nyaupane, 2011). Consequently, there is an absence of understanding on host-children's Quality of Life (QOL), which is a holistic concept referring to individuals' satisfaction with life and their experience in the world by taking into account both objective and subjective wellbeing. As most literature reviewed in this study has predominantly investigated objective wellbeing, future research is encouraged to explore the

480 QOL of host-children with specific attention given to their subjective wellbeing; this 481 information will help policy makers to protect host-children. 


\subsection{Reflecting Children's Voices}

The findings revealed that fewer than half of the studies analysed were empirical studies.

484

485

486

487

488

489

490

491

492

494

495

496

497

498

499

500

501

502

503

504

505

506

In particular, few studies under the Child Labourer theme collected empirical data because of the sensitivity and potentially traumatic issues inherent in the topic. Among studies with an empirical approach, less than half involved children despite the much-argued benefits of including children's voices (Canosa et al., 2016; Poria \& Timothy, 2014). Two explanations are offered to decipher the lack of children's voices in tourism. First, researchers are required to possess the specialised research techniques and knowledge to obtain information from the children who have limited cognitive and language competencies (Khoo-Lattimore, 2015; Poria \& Timothy, 2014). Second, involving children in tourism research is a deterrent for researchers due to perceived ethical complexity (Canosa \& Graham, 2016; Khoo-Lattimore, 2015). To involve children, the researchers should consider the benefits, consequence and potential risks of the research, and the consent of the children's guardians (Canosa \& Graham, 2016; Graham, Powell, Taylor, Anderseon, \& Fitzgerald, 2013) as well as the children themselves (KhooLattimore, 2018). In this review, a majority of studies involving children did not explicitly or extensively address methodological and ethical issues; most simply mentioned the consent of children's guardians. Researchers who want to involve children in their research, should consider not only the guardians of children's consent to participate in research, but also the positive and negative impacts of their research on the children, and willingness of children themselves to participate (Canosa \& Graham, 2016; Graham et al., 2013).

In order to gain reliable information from children, researchers need to pay specific attention to the research instrument. Ethnography was one of the most frequently adopted method in researching host-children. Ethnography is a useful technique to investigate sensitive issues such as child labourers and child sex workers (Fabinyi, Knudsen, \& Segi, 2010; O'Byrne, 2007). In ethnography research, the researcher should build trust with the informants and be 
sensitive towards the social setting and values (O'Byrne, 2007). However, ethnography requires highly skilled researchers and data collection over a prolonged period.

Visual method was the other prevalent technique to involve children. Visual method is

510 a useful technique in social studies as it allows more holistic depiction regarding informants' 511 perception of space, time and identity (Literat, 2013). From a psychological perspective, visual method gives informants time to reflect on their response and discover their subconscious

513 feelings (Literat, 2013). In addition, visual method is particularly child-friendly because it 514 captivates children's attention, reduces power distance between researchers and children, and 515 depends less on linguistic proficiency (Literat, 2013). However, visual data could potentially 516 be mis- or over-interpreted (Literat, 2013), thus triangulation with traditional methods such as interview, observation and ethnography is necessary (Literat, 2013; Punch, 2002). According to Punch (2002), the use of a combination of techniques can interest and captivate the children and at the same time can effectively generate useful and relevant data. It can also alleviate methodological issues of involving children by cross-checking data and preventing biases arising from overreliance on one methods (Literat, 2013; Punch, 2002). Despite the advantages of combining visual and traditional methods, no study in this review has attempted to include children's voices using multiple methods, except for Monterrubio et al. (2016) who identified the social dimensions of child labourers by using both ethnography and drawing methods.

\section{Conclusion}

While this review has provided insights into the interdisciplinary research on hostchildren, it is not exempted from limitations. First, the ages of host-children in the literature were not considered in the review, which aimed to draw an overall trajectory of existing literature. Children's age is a critical parameter of research (Khoo-Lattimore, 2015; Poria \&

530 Timothy, 2014) and therefore, future research and review are recommended to consider the ages of host-children. Furthermore, only journal articles and book chapters published in 
532 English were reviewed. Future research may wish to widen this review by analysing a broader

533

534

range of literature including conference papers, reviews and editorials published in other languages.

This review has contributed to existing knowledge on children in tourism in three ways.

First, it identified the research gap by highlighting the dearth of knowledge on children from a host rather than a tourist perspective. Within this gap, the review unveils the paucity of attention to general child labour and the absence of children's own perspectives and voices. Second, this review makes ethical and methodological contributions to existing studies on host-children by calling for future researchers to prudently consider ethical issues and triangulate visual with traditional methods when researching children. Finally, any stakeholders who have an interest in host-children, such as NGOs, intergovernmental organisations and governments, can use the information from the review to understand the status of host-children investigations. This understanding would aid in identifying the directions for future grant funding and subsequently, strategizing to better protect host-children at destinations.

\section{References}

Agyeiwaah, E., Akyeampong, O., Boakye, K. A., \& Adu-Gyamfi, A. B. (2014). Pros and cons of hosting international tourists: Is it rational? Tourism Planning and Development, 11(4), 435-451. doi:10.1080/21568316.2014.884979

Al-Frehat, M. M., \& Alhelalat, J. A. (2015). A study on the educational status of Tourism child labourers in Petra, Jordan. Mediterranean Journal of Social Sciences, 6(4), 20-29. doi:10.5901/mjss.2015.v6n4s2p20

Alexander, S., Meuwese, S., \& Wolthuis, A. (2000). Policies and developments relating to the sexual exploitation of children: The legacy of the Stockholm conference. European Journal on Criminal Policy and Research, 8(4), 479-501. doi:10.1023/A:1008759107302

Allan, M. (2014). Geotourism: Why do children visit geological tourism sites? Dirasat: Human and Social Sciences, 41, 653-661. doi:10.12816/0026939

Andereck, K. L., \& Nyaupane, G. P. (2011). Exploring the bature of tourism and quality of life perceptions among residents. Journal of Travel Research, 50(3), 248-260. doi:10.1177/0047287510362918

Anderson-Fye, E. P. (2004). A"coca-cola" shape: Cultural change, body image, and eating disorders in San Andres, Belize. Culture Medicine and Psychiatry, 28(4), 561-595. doi:10.1007/s11013-004-1068-4 
600

601

602

603

604

605

606

607

608

609

610

611

612

613

Backer, E., \& Schänzel, H. (2013). Family holidays-vacation or obli-cation? Tourism Recreation Research, 38(2), 159-173. doi:10.1080/02508281.2013.11081742

Bakas, F. E. (2018). The political economy of tourism: Children's neglected role. Tourism Analysis, 23(2), 215-225. doi:10.3727/108354218X15210313504562

Bandyopadhyay, R. (2012). Child-sex tourism, HIV/AIDS, and social justice in India. Peace Review, 24(2), 143-146. doi:10.1080/10402659.2012.677320

Barakat-Haddad, C., \& Dghaim, R. (2015). Adolescent health risk behaviors in a migrant population. In J. A. Jaworski (Ed.), Advances in sociology research (pp. 1-27). New York: Nova Science Publisher.

Beddoe, C. (2003). Ending child sex tourism: A vision for the future. In T. G. Bauer \& B. McKercher (Eds.), Sex and tourism: Journeys of romance, love, and lust (pp. 196-208). New York: Haworth Hospitality Press.

Bocij, P., \& McFarlane, L. (2003). The internet: A discussion of some new and emerging threats to young people. Police Journal, 76(1), 3-13. doi:10.1177/0032258X0307600102

Buchitchon, S. (2016). The protection of children born from assisted reproductive technology act 2015: Scientific advances, ethics and concerns over the use of human embryo. Advanced Science Letters, 22(5-6), 1610-1613. doi:10.1166/asl.2016.6702

Buzinde, C. N., \& Manuel-Navarrete, D. (2013). The social production of space in tourism enclaves: Mayan children's perceptions of tourism boundaries. Annals of Tourism Research, 43, 482-505. doi:10.1016/j.annals.2013.06.003

Bylth, E., \& Farrand, A. (2005). Reproductive tourism - A price worth paying for reproductive autonomy? Critical Social Policy, 25(1), 91-114. doi:10.1177/0261018305048969

Canosa, A., \& Graham, A. (2016). Ethical tourism research involving children. Annals of Tourism Research, 61, 219-221. doi:10.1016/j.annals.2016.07.006

Canosa, A., Moyle, B., \& Wray, M. (2016). Can anybody hear me? A critical analysis of young residents' voices in tourism studies. Tourism Analysism, 20(2-3), 325-337. doi: $10.3727 / 108354216 X 14559233985097$

Canosa, A., Wilson, E., \& Graham, A. (2017). Empowering young people through participatory film: A postmethodological approach. Current Issues in Tourism, 20(8), 894-907. doi:10.1080/13683500.2016.1179270

Carpenter, K. (2015). Childhood studies and orphanage tourism in Cambodia. Annals of Tourism Research, 55, 15-27. doi:10.1016/j.annals.2015.08.010

Chheang, V. (2008). The political economy of tourism in Cambodia. Asia Pacific Journal of Tourism Research, 13(3), 281-297. doi:10.1080/10941660802280414

Cross, B. (2006). Infinite rehearsal of culture in St Catherine Jamaica: Heritage as tourist product, implications for Caribbean pedagogy. Pedagogy, Culture and Society, 14(3), 315-327. doi:10.1080/14681360600891928

Dancause, K. N., Dehuff, C., Soloway, L. E., Vilar, M., Chan, C., Wilson, M., . . Garruto, R. M. (2011). Behavioral changes associated with economic development in the South Pacific: health transition in Vanuatu. American journal of human biology, 23(3), 366376. doi:10.1002/ajhb.21146

Dewey, S., \& Conver, L. (2012). Children as barometers of social decay: Perceptions of child sex tourism in Goa, India. In S. Dewey \& K. J. Brison (Eds.), Super girls, gangstas, freeters, and xenomaniacs; gender and modernity in global youth cultures (pp. 166190). Portland: Syracuse University Press.

Dredge, D., Benckendorff, P., Day, M., Gross, M. J., Walo, M., Weeks, P., \& Whitelaw, P. (2012). The philosophic practitioner and the curriculum space. Annals of Tourism Research, 39(4), 2154-2176. doi:10.1016/j.annals.2012.07.017 
Eades, J. (2007). Sex tourism and the internet: Information, amplification, and moral panics. In W. Pease, M. Rowe, \& M. Cooper (Eds.), Information and communication technologies in support of the tourism industry (pp. 260-284). Hershey, PA: Idea Group Pub.

Fabinyi, M., Knudsen, M., \& Segi, S. (2010). Social complexity, ethnography and coastal resource management in the Philippines. Coastal Management, 38(6), 617-632. doi: 10.1080/08920753.2010.523412

Franklin, A., \& Crang, M. (2001). The trouble with tourism and travel theory? Tourist Studies, 1(1), 5-22. doi:10.1177/146879760100100101

Freidus, A. L. (2017). Unanticipated outcomes of voluntourism among Malawi's orphans. Journal of Sustainable Tourism, 25(9), 1306-1321. doi:10.1080/09669582.2016.1263308

Gamradt, J. (1995). Jamaican children's representations of tourism. Annals of Tourism Research, 22(4), 735-762. doi:10.1016/0160-7383(95)00024-7

Gössling, S., Schumacher, K., Morelle, M., Berger, R., \& Heck, N. (2004). Tourism and street children in Antananarivo, Madagascar. Tourism and Hospitality Research, 5(2), 131149. doi:10.1057/palgrave.thr.6040012

Graham, A., Powell, M. A., Taylor, N., Anderseon, D. L., \& Fitzgerald, R. M. (2013). Ethical research involving children. UNICEF Office of Research. Retrieved from http://childethics.com/

Gram, M. (2005). Family holidays. A qualitative analysis of family holiday experiences. Scandinavian Journal of Hospitality and Tourism, 5(1), 2-22. doi:10.1080/15022250510014255

Guiney, T. (2018). 'Hug-an-orphan vacations':'love'and emotion in orphanage tourism. The Geographical Journal, 184(2), 125-137. doi:10.1111/geoj.12218

Guiney, T., \& Mostafanezhad, M. (2015). The political economy of orphanage tourism in Cambodia. Tourist Studies, 15(2), 132-155. doi:10.1177/1468797614563387

Hagedoorn, E. (2013). Child labour and tourism: how travel companies can reduce child labour in tourism destinations. Retrieved from Faire Trade Tourism Wegsite: http://www.fairtrade.travel/source/websites/fairtrade/documents/Child_Labour_and_T ourism_OP_25_May_2013.pdf

Hansson, T., Carey, G., \& Kjartansson, R. (2010). A multiple software approach to understanding values. Journal of Beliefs and Values, 31(3), 283-298. doi:10.1080/13617672.2010.521005

Härkönen, E., Linköpings, u., Affärsrätt, \& Filosofiska, f. (2016). Corporate liability and international child sex tourism - with special reference to the regulation in the Nordic countries. Scandinavian Journal of Hospitality and Tourism, 16(3), 315-332. doi:10.1080/15022250.2015.1108861

Harrison, L. (2014). "I am the baby's real mother": Reproductive tourism, race, and the transnational construction of kinship. Women's Studies International Forum, 47, 145156. doi:10.1016/j.wsif.2014.06.007

Healey, M., \& Healey, R. L. (2010). How to conduct a literature search. In N. Clifford, M. Cope, T. Gillespie, \& S. French (Eds.), Key methods in geography (pp. 16-34). Los Angeles: Sage.

Higgins-Desbiolles, F. (2006). More than an "industry": The forgotten power of tourism as a social force. Tourism Management, 27(6), 1192-1208. doi:10.1016/j.tourman.2005.05.020

Himmelgreen, D. A., Romero-Daza, N., Amador, E., \& Pace, C. (2012). Tourism, economic insecurity, and nutritional health in rural Costa Rica: Using syndemics theory to 
understand the impact of the globalizing economy at the local level. Annals of Anthropological Practice, 36(2), 346-364. doi:10.1111/napa.12008

Hogan, C. L. (2007). Touring Commerce Clause Jurisprudence: The Constitutionality of Prosecuting Non-Commercial Sexually Illicit Acts under 18 USC Section 2423 (C). St. John's Law, 81(3), 641.

Indulska, M., Hovorka, D. S., \& Recker, J. (2012). Quantitative approaches to content analysis: Identifying conceptual drift across publication outlets. European Journal of Information Systems, 21(1), 49-69. doi:10.1057/ejis.2011.37

International Labour Organization. (2002). A future without child labour: Global report under the follow-up to the ILO declaration on fundamental principles and rights at work. Retrieved from International Labour Organization Website: https://www.ilo.org/wcmsp5/groups/public/---dgreports/---dcomm/--publ/documents/publication/wcms_publ_9221124169_en.pdf

International Labour Organization. (2017). Global estimates of child labour: Results and trends, 2012-2016. Retrieved from International Labour Organization: https://www.ilo.org/wcmsp5/groups/public/@dgreports/@dcomm/documents/publicat ion/wcms_575499.pdf

Jensen, L., Marlin, J., Dyck, D., \& Laubach, H. (2009). Effect of tourism and trade on intestinal parasitic infections in Guatemala. Journal of Community Health, 34(2), 98-101. doi:10.1007/s10900-008-9130-8

Johnson, A. K. (2011). International child sex tourism: Enhancing the legal response in South East Asia. The International Journal of Children's Rights, 19(1), 55-79. doi:10.1163/157181810X499367

Johnson, A. K. (2014). Protecting children's rights in Asian tourism. The International Journal of Children's Rights, 22(3), 581-617. doi:10.1163/15718182-02201001

Kalargyrou, V., \& Woods, R. (2015). An exploratory study of child commercial sexual exploitation in the hospitality industry in the United States. Hospitality and Society, 5(1), 43-69. doi:10.1386/hosp.5.1.43_1

Khoo-Lattimore, C. (2015). Kids on board: Methodological challenges, concerns and clarifications when including young children's voices in tourism research. Current Issues in Tourism, 18(9), 845-858. doi:10.1080/13683500.2015.1049129

Khoo-Lattimore, C. (2018). The Effect of Motherhood on Tourism Fieldwork with Young Children: An Autoethnographic Approach. In Porter, B. A., \& Schänzel, H.(Eds). Femininities in the Field. Tourism and Transdisciplinary Research, Channel View Publications.

Khoo-Lattimore, C., delChiappa, G., \& Yang, M. J. (2018). A family for the holidays: Delineating the hospitality needs of European parents with young children. Young Consumers, 19(2), 159-171. doi:10.1108/YC-08-2017-00730

Khoo-Lattimore, C., Mura, P., \& Yung, R. (2017). The time has come: a systematic literature review of mixed methods research in tourism. Current Issues in Tourism, 1-20. doi:10.1080/13683500.2017.1406900

Khoo-Lattimore, C., Prayag, G., \& Cheah, B. L. (2015). Kids on board: Exploring the choice process and vacation needs of Asian parents with young children in resort hotels. Journal of Hospitality Marketing and Management, 24(5), 511-531. doi:10.1080/19368623.2014.914862

Kim, C. S., Bai, B. H., Kim, P. B., \& Chon, K. (2018). Review of reviews: A systematic analysis of review papers in the hospitality and tourism literature. International Journal of Hospitality Management, 70, 49-58. doi:10.1016/j.ijhm.2017.10.023 
753

754

755

756

757

758

Klaver, F. R. M. (2015). A clash with volunteer tourists? An extreme case study in Guatemala. Worldwide Hospitality and Tourism Themes, 7(2), 189-200. doi:10.1108/WHATT-122014-0048

Kosuri, M. D., \& Jeglic, E. L. (2017). Child sex tourism: American perceptions of foreign victims. Journal of Sexual Aggression, 23(2), 207-221. doi:10.1080/13552600.2016.1231350

Leatherman, T. L., Goodman, A. H., \& Stillman, T. (2010). Changes in stature, weight, and nutritional status with tourism-based economic development in the Yucatan. Economics and Human Biology, 8(2), 153-158. doi:10.1016/j.ehb.2010.05.008

Leung, P. (2003). Child sex tourism. Tourism Recreation Research, 28(2), 83-87. doi:10.1080/02508281.2003.11081407

Levesque, R. J. R. (1995). Combatting child sexual maltreatment: Advances and obstacles in international progress. Law and Policy, 17(4), 441-469. doi:10.1111/j.14679930.1995.tb00158.x

Literat, I. (2013). "A pencil for your thoughts": participatory drawing as a visual research method with children and youth. International Journal of Qualitative Methods, 12(1), 84-98. doi:10.1177/160940691301200143

Llorca-Rodríguez, C. M., Casas-Jurado, A. C., \& García-Fernández, R. M. (2016). The regional polarization of tourism's contribution to economic growth in Peru: alternative solutions. Tourism Economics, 22(2), 397-415. doi:10.5367/te.2014.0425

Magablih, K., \& Naamneh, M. (2010). Child labor in the tourism industry in Jordan. Tourism Analysis, 15(1), 89-97. doi:10.3727/108354210X12724734223711

Mays, M., Pope, C., \& Popay, J. (2005). Systematically reviewing qualitative and quantitative evidence to inform management and policy-making in the health field. Journal of Helath Services Research \& Policy, 10(1), 6-20.doi: 10.1258/1355819054308576

Miller, J. (2011). Beach boys or sexually exploited children? Competing narratives of sex tourism and their impact on young men in Sri Lanka's informal tourist economy. Crime, law and social change, 56(5), 485-508.

Mitchell, L. M. (2006). Child-centered? Thinking critically about children's drawing as a visual research method. Visual Anthropology Review, 22(1), 60-73.

Moher, D., Liberati, A., Tetzlaff, J., Altman, D. G., \& Group, P. (2009). Reprint-preferred reporting items for systematic reviews and meta-analyses: the PRISMA statement. Physical Therapy, 89(9), 873-880. doi:10.1093/ptj/89.9.873

Molero, F., Navas, M. a. S., Alema' n, P., \& Cuadrado, I. (2003). Paupers or riches: The perception of immigrants, tourists and ingroup members in a sample of Spanish children. Journal of Ethnic and Migration Studies, 29(3), 501-518. doi:10.1080/13691830305617

Monterrubio, C., Rodríguez-Muñoz, G., \& Durán-Barrios, J. M. (2016). Social dimensions of child tourism labour: Listening to children's voices in two Mexican rural communities. International Journal of Tourism Policy, 6(2), 147-165. doi:10.1504/IJTP.2016.077969

Montgomery, H. (2008). Buying Innocence: Child-sex tourists in Thailand. Third World Quarterly, 29(5), 903-917. doi:10.1080/01436590802106023

Morrow, V. (2011) Understanding children and childhood (Centre for Children and Young People Background Briefing Series, No. 1, $2^{\text {nd }}$ ed). Lismore, New South Wales, Australia: Southern Cross University. Centre for Children and Young People.

Muñoz-Fernández, G. A., Rodríguez-Gutiérrez, P., \& Santos-Roldán, L. (2016). Entrepreneurship in higher education in tourism, gender issue? Electronic Journal of Research in Educational Psychology, 14(1), 45-66. doi:10.14204/ejrep.38.15040 
Muto, K. (2010). Organ transplantation as a family issue: Living liver donors in japan. International Journal of Japanese Sociology, 19(1), 35-48. doi:10.1111/j.14756781.2010.01135.x

Newnham, D. (2007). Late adolescent peer group formation in an international hotel school. International Journal of Contemporary Hospitality Management, 19(2), 159-168. doi:10.1108/09596110710729265

Nickerson, N. P., \& Jurowski, C. (2001). The influence of children on vacation travel patterns. Journal of Vacation Marketing, 7(1), 19-30. doi:10.1177/135676670100700102

O'Byrne, P. (2007). The advantages and disadvantages of mixing methods: An analysis of combining traditional and autoethnographic approaches. Qualitative Health Research, 17(10), 1381-1391. doi:10.1177/1049732307308304

Ohashi, Y., Ohashi, K., Meskanen, P., Hummelin, N., Kato, F., \& Kynäslahti, H. (2012). What children and youth told about their home city in digital stories in ' $\mathrm{C}$ my city!'. Digital Creativity, 23(2), 126-135. doi:10.1080/14626268.2012.709942

Pegas, F., Coghlan, A., \& Rocha, V. (2012). An exploration of a mini-guide programme: Training local children in sea turtle conservation and ecotourism in Brazil. Journal of Ecotourism, 11(1), 48-55. doi:10.1080/14724049.2011.631710

Perumal, J. C. (2013). Pedagogy of refuge: Education in a time of dispossession. Race Ethnicity and Education, 16(5), 673-695. doi:10.1080/13613324.2013.792797

Petticrew, M. (2001). Systematic reviews from astronomy to zoology: Myths and misconceptions. Bmj, 322(7278), 98-101. doi:10.1136/bmj.322.7278.98

Pickering, C., \& Byrne, J. (2014). The benefits of publishing systematic quantitative literature reviews for $\mathrm{PhD}$ candidates and other early-career researchers. Higher Education Research and Development, 33(3), 534-548. doi:10.1080/07294360.2013.841651

Pollard, T. M., Ward, G. A., Thornley, J., Wooster, G., Wooster, J., \& Panter-Brick, C. (2000). Modernisation and children's blood pressure: On and off the tourist trail in Nepal. American Journal of Human Biology, 12(4), 478-486. doi:10.1002/15206300(200007/08)12:4<478::AID-AJHB7>3.0.CO;2-0

Poria, Y., \& Timothy, D. J. (2014). Where are the children in tourism research? Annals of Tourism Research, 47, 93-95. doi:10.1016/j.annals.2014.03.002

Powell, M. A., McArthur, M., Chalmers, J., Graham, A., Moore, T., Spriggs, M., \& Taplin, S. (2018). Sensitive topics in social research involving children. International Journal of Social Research Methodology, 21(6), 647-660. doi:10.1080/13645579.2018.1462882

Proyrungroj, R. (2017). Orphan volunteer tourism in Thailand: Volunteer tourists' motivations and on-Site experiences. Journal of Hospitality and Tourism Research, 41(5), 560-584. doi:10.1177/1096348014525639

Puharić, Z., Slijepčević, M. K., Badrov, T., \& Petričević, N. (2016). Gambling among teenagers in bjelovar-bilogora county (Croatia). Alcoholism and Psychiatry Research, 52(1), 5-16.

Punch, S. (2002). Research with children: the same or different from research with adults? Childhood, 9(3), 321-341. doi:10.1177/0907568202009003005

Reas, P. J. (2015). 'So, child protection, I'll make a quick point of it now': Broadening the notion of child abuse in volunteering vacations in Siem Reap, Cambodia. Tourism Review International, 18(4), 295-309. doi:10.3727/154427215X14230549904170

Rogerson, J. M., \& Slater, D. (2014). Urban volunteer tourism: Orphanages in Johannesburg. Urban Forum, 25(4), 483-499.

Rotabi, K. S., Roby, J. L., \& McCreery Bunkers, K. (2016). Altruistic exploitation: Orphan tourism and global social work. British Journal of Social Work, 47(3), 648-665. doi:10.1093/bjsw/bcv147 
Sinervo, A., \& Hill, M. D. (2011). The visual economy of Andean childhood poverty: Interpreting postcards in Cusco, Peru. The Journal of Latin American and Caribbean Anthropology, 16(1), 114-142. doi:10.1111/j.1935-4940.2011.01127.x

Smith, A. E., \& Humphreys, M. S. (2006). Evaluation of unsupervised semantic mapping of natural language with Leximancer concept mapping. Behavior Research Methods, 38(2), 262-279. doi:10.3758/BF03192778

Soliman, H. H., Alsharqawi, N. I., \& Younis, M. A. (2018). Is tourism marriage of young girls in egypt a form of child sexual abuse? A family exploitation perspective. Journal of Child Sexual Abuse, 27(2), 122-140. doi:10.1080/10538712.2018.1425945

Sotiriadou, P., Brouwers, J., \& Le, T.-A. (2014). Choosing a qualitative data analysis tool: A comparison of NVivo and Leximancer. Annals of Leisure Research, 17(2), 218-234. doi:10.1080/11745398.2014.902292

Spurrier, K. J., \& Alpaslan, A. (2017). Adult survivors' recollections and accounts of their involvement in child sex tourism by way of child prostitution. Social Work, 53(3), 388408. doi:10.15270/52-2-577

Tepelus, C. M. (2006). A model for multi-stakeholder partnerships on human rights in tourism. In J. Jonker \& M. d. Witte (Eds.), Management models for corporate social responsibility (pp. 82-89). Berlin, Heidelberg: Springer.

Tepelus, C. M. (2008). Social responsibility and innovation on trafficking and child sex tourism: Morphing of practice into sustainable tourism policies? Tourism and Hospitality Research, 8(2), 98-115. doi:10.1057/thr.2008.10

The United Nations. (2010). The United Nations Convention on the Rights of the Child. Ireland: Children's Rights Alliance. Retrieved from https://www.childrensrights.ie/sites/default/ files/submissions_reports/files/UNCRCEnglish_0.pdf

Tirasattayapitak, S., Chaiyasain, C., \& Beeton, R. J. S. (2015). The impacts of nature-based adventure tourism on children in a Thai village. Tourism Management Perspectives, 15, 122-127. doi:10.1016/j.tmp.2015.05.003

Tomazos, K., \& Butler, R. (2012). Volunteer tourists in the field: A question of balance? Tourism Management, 33(1), 177-187. doi:10.1016/j.tourman.2011.02.020

Tseng, C., Wu, B., Morrison, A. M., Zhang, J., \& Chen, Y.-c. (2015). Travel blogs on China as a destination image formation agent: A qualitative analysis using Leximancer. Tourism Management, 46, 347-358. doi:10.1016/j.tourman.2014.07.012

Vanclay, F. (2003). International principles for social impact assessment. Impact Assessment and Project Appraisal, 21(1), 5-12. doi:10.3152/147154603781766491

Wang, E. C. (2014). The problem of hospitality in J.M. Coetzee's the Childhood of Jesus. Foreign Literature Studies, 36(1), 35-44.

Wearing, S. (2002). Re-centering teh self in volunteer tourism. In G. M. S. Dann (Ed.), The tourist as a metaphor of the social world (pp. 237-262). New York: Cabi publishing.

Wilson, L. (2015). Finding the win-win: Providing supportive and enriching volunteer tourism experiences while promoting sustainable social change. Worldwide Hospitality and Tourism Themes, 7(2), 201-207. doi:10.1108/WHATT-12-2014-0045

Wu, M.-Y., Wall, G., \& Pearce, P. L. (2014). Shopping experiences: international tourists in Beijing's silk market. Tourism Management, 41, 96-106. doi:10.1016/j.tourman.2013.09.010

Yang, E. C. L. (2017). Risk taking on her lonely planet: Exploring the risk experiences of Asian solo female travellers (Unpublished doctoral dissertation). Griffith University, Australia.

Yang, E. C. L., Khoo-Lattimore, C., \& Arcodia, C. (2017). A systematic literature review of risk and gender research in tourism. Tourism Management, 58, 89-100. doi:10.1016/j.tourman.2016.10.011 
858 Yung, R., \& Khoo-Lattimore, C. (2017). New realities: A systematic literature review on 859 virtual reality and augmented reality in tourism research. Current Issues in Tourism, 1860 26. doi: $10.1080 / 13683500.2017 .1417359$ 
Table 1.

Top Seven Journals Addressing Host-Children

\begin{tabular}{ll}
\hline Journal Titles & Number of Articles \\
\hline Annals of Tourism Research & 3 \\
Tourism Analysis & 3 \\
American Journal of Human & 2 \\
Biology & \\
International Journal of & 2 \\
Children's Rights & 2 \\
St. John's Law Review & 2 \\
$\begin{array}{l}\text { Tourism and Hospitality } \\
\text { Research }\end{array}$ & \\
Worldwide Hospitality and & 2 \\
Tourism Themes & \\
\hline
\end{tabular}


Table 2.

Tourism Journals Addressing Host-Children

Titles of Tourism Journals

Number of

Articles

1 Annals of Tourism Research 3

2 Tourism Analysis 3

3 Tourism and Hospitality Research 2

4 Worldwide Hospitality and Tourism Themes 2

5 Cornell Hotel and Restaurant Administration Quarterly 1

6 Current Issues in Tourism 1

7 Hospitality and Society 1

8 International Journal of Contemporary Hospitality Management 1

9 International Journal of Tourism Policy 1

10 Journal of Ecotourism 1

11 Journal of Hospitality and Tourism Research 1

12 Journal of Sustainable Tourism 1

13 Tourism Management 1

14 Tourism Management Perspectives 1

15 Tourism Planning and Development 1

16 Tourism Recreation Research 1

17 Tourism Review International 1

18 Tourist Studies 1

In total 24


Table 3.

The Number of Studies in Each Theme

\begin{tabular}{ll}
\hline Themes & Number of Articles \\
\hline Child Labourer & 40 \\
Child-Resident & 16 \\
Voluntourism & 11 \\
Others & 2 \\
\hline
\end{tabular}

Note. One study was coded on multiple themes 


\section{Table 4.}

11 theoretical frameworks/concepts adopted in host-children research

\begin{tabular}{|c|c|c|c|c|}
\hline Themes & Theories & Authors & Disciplines & Foci \\
\hline \multirow{7}{*}{$\begin{array}{l}\text { Child } \\
\text { Labourer }\end{array}$} & \multirow{3}{*}{$\begin{array}{l}\text { Corporate Social } \\
\text { Responsibility } \\
\text { (CSR) }\end{array}$} & $\begin{array}{l}\text { Kalargyrou and } \\
\text { Woods (2015) }\end{array}$ & Hospitality & $\begin{array}{l}\text { To explore how the hospitality industry } \\
\text { contributes to combatting child sex tourism }\end{array}$ \\
\hline & & Tepelus (2008) & $\begin{array}{l}\text { Tourism/ } \\
\text { Hospitality }\end{array}$ & $\begin{array}{l}\text { To present practices for combatting human } \\
\text { trafficking and its links with the tourism } \\
\text { and child sex tourism }\end{array}$ \\
\hline & & Tepelus (2006) & Sociology & $\begin{array}{l}\text { To integrate child sex tourism issues in } \\
\text { sustainable tourism through multi- } \\
\text { stakeholders }\end{array}$ \\
\hline & $\begin{array}{l}\text { In-group Bias } \\
\text { theory }\end{array}$ & $\begin{array}{l}\text { Kosuri and } \\
\text { Jeglic (2017) }\end{array}$ & Politics & $\begin{array}{l}\text { To examine the relationships between } \\
\text { Americans' perceptions of child sex tourism } \\
\text { and cultures of the host-destinations }\end{array}$ \\
\hline & $\begin{array}{l}\text { Orientalism } \\
\text { Concepts of } \\
\text { Power }\end{array}$ & $\begin{array}{l}\text { Bandyopadhyay } \\
(2012)\end{array}$ & Sociology & $\begin{array}{l}\text { To investigate the role of child sex tourism } \\
\text { in the spread of HIV/AIDS }\end{array}$ \\
\hline & $\begin{array}{l}\text { Biological } \\
\text { Systems }\end{array}$ & $\begin{array}{l}\text { Spurrier and } \\
\text { Alpaslan (2017) }\end{array}$ & Sociology & $\begin{array}{l}\text { To gain an understanding of child sex } \\
\text { tourism's impacts on the lives of survivors } \\
\text { who used to be child prostitutes }\end{array}$ \\
\hline & Critical Feminism & Bakas (2018) & Tourism & $\begin{array}{l}\text { To explore the impact of child labour on } \\
\text { their parents' gendered entrepreneurial roles }\end{array}$ \\
\hline
\end{tabular}

Child -

Resident
Transformation of the self
Gamradt (1995) Tourism

Guiney (2018)

Geography

Tourism/ Hospitality

Hofstede's Individualism

Klaver (2015)

Guiney and

Double

Voluntourism
Movement

Symbolic

violence

Civilised

Oppression

Abuse in the

Benign

Reas (2015)

Tourism

Tourism (2015)

Altruistic Exploitation
Rotabi et al. (2016)
To describe the layered emotional entanglements within orphanage tourism

To examine the conflicts from the volunteering experience of individualistic voluntourists and collectivistic local people

To articulate, facilitate and resist the neoliberalisation of orphanages through orphanage tourism in Cambodia

To critically examine the commodification of voluntourism and vacation fantasy

To explore the ironic juxtaposition of benefits and harms related to orphan tourism 
Table 5.

Informant of the 34 Empirical Studies

\begin{tabular}{|c|c|c|c|}
\hline & $\begin{array}{l}\text { Child Labourer } \\
(\mathrm{n}=11)\end{array}$ & $\begin{array}{l}\text { Child-Resident } \\
(\mathrm{n}=15)\end{array}$ & $\begin{array}{l}\text { Voluntourism } \\
(\mathrm{n}=8)\end{array}$ \\
\hline Number of Studies Not Including Children & 6 & 2 & 7 \\
\hline Children's guardians & 1 & 1 & 0 \\
\hline Local adults & 0 & 1 & 0 \\
\hline Tourists & 1 & 1 & 7 \\
\hline Past-child labours & 1 & $\mathrm{~N} / \mathrm{A}$ & 0 \\
\hline Government & 0 & 0 & 1 \\
\hline $\begin{array}{l}\text { Non-Government / Non-Profit } \\
\text { Organisations }\end{array}$ & 3 & 0 & 3 \\
\hline Private Businesses & 2 & 0 & 0 \\
\hline Number of Studies Including Children & 5 & 13 & 1 \\
\hline Number of Studies Including Only Children & 3 & 8 & 0 \\
\hline $\begin{array}{l}\text { Number of Studies Including Children with } \\
\text { Others }\end{array}$ & 2 & 5 & 1 \\
\hline Children's guardians & 1 & 1 & 0 \\
\hline Local adults & 0 & 3 & 0 \\
\hline Tourists & 0 & 1 & 1 \\
\hline Government & 1 & 0 & 0 \\
\hline Non-Government Organisation & 1 & 0 & 0 \\
\hline
\end{tabular}

Note. Several studies collected data from multi-informants. 
Table 6.

Research techniques adopted in the 19 studies involving children

\begin{tabular}{cllll}
\hline & $\begin{array}{l}\text { Child } \\
\text { Labourer } \\
(\mathrm{n}=5)\end{array}$ & $\begin{array}{l}\text { Host- } \\
\text { Community } \\
(\mathrm{n}=13)\end{array}$ & $\begin{array}{l}\text { Voluntourism } \\
(\mathrm{n}=1)\end{array}$ & In total \\
\hline Qualitative (n=13) & & 2 & 0 & 5 \\
$\quad$ Ethnography & 3 & 4 & 0 & 5 \\
$\quad$ Visual method & 1 & 2 & 0 & 3 \\
$\quad \begin{array}{l}\text { Interview } \\
\text { Quantitative (n=7) }\end{array}$ & 1 & 3 & 1 & 4 \\
Test & 0 & 2 & 0 & 3 \\
Survey & 1 & & & \\
\hline
\end{tabular}

Note. One study used both an ethnography and visual method. 
Table 7. Summary of review findings and key insights

\begin{tabular}{|c|c|c|}
\hline Findings & Key Insights & Directions for Future Research \\
\hline $\begin{array}{l}\text { Disciplines of Host- } \\
\text { Children Literature: } \\
\text { Despite the } \\
\text { interdisciplinary nature of } \\
\text { host-children, limited } \\
\text { scholarly attention has been } \\
\text { paid to host-children, } \\
\text { regardless of disciplines. } \\
\text { 3.3. Theoretical } \\
\text { Framework: Lack of } \\
\text { engagement with } \\
\text { theoretical frameworks was } \\
\text { observed. }\end{array}$ & $\begin{array}{l}\text { There is a paucity of } \\
\text { host-children research } \\
\text { in interdisciplinary } \\
\text { literature. }\end{array}$ & $\begin{array}{l}\text { Host-children should be explored from } \\
\text { a broader perspective, not just the } \\
\text { economic aspect, by acknowledging } \\
\text { that tourism is a social force with } \\
\text { transformative and disruptive power } \\
\text { over host-community. } \\
\text { Future research on host-children should } \\
\text { focus on theoretical development and } \\
\text { seek to break new conceptual and } \\
\text { ethical ground. }\end{array}$ \\
\hline $\begin{array}{l}\text { Themes of Host-Children } \\
\text { Studies: Although Child } \\
\text { Labour is the biggest theme } \\
\text { in the host-children } \\
\text { literature, most of the } \\
\text { research has focused on } \\
\text { child sex workers. } \\
\text { Consequently, general child } \\
\text { labourers other than child } \\
\text { sex workers have been } \\
\text { neglected in the } \\
\text { interdisciplinary literature. } \\
\text { Host Countries: South Asia } \\
\text { and South-East Asia is the } \\
\text { most common context. } \\
\text { However, although the } \\
\text { child labour issue is } \\
\text { extremely serious in the } \\
\text { Asia/Pacific and Sub } \\
\text { Saharan Africa regions, the } \\
\text { existing literature has } \\
\text { focused on mostly child sex } \\
\text { workers, neglecting general } \\
\text { child labourers. }\end{array}$ & $\begin{array}{l}\text { General child labourers } \\
\text { have been neglected in } \\
\text { the interdisciplinary } \\
\text { research while child sex } \\
\text { workers have received } \\
\text { more attention. }\end{array}$ & $\begin{array}{l}\text { The interdisciplinary research should } \\
\text { explore general child labourer in the } \\
\text { Asian and African regions to deepen } \\
\text { existing knowledge. }\end{array}$ \\
\hline $\begin{array}{l}\text { Themes of Host-Children } \\
\text { Studies: It was identified } \\
\text { that most of the research } \\
\text { had explored the objective } \\
\text { dimension of tourism } \\
\text { impacts, such as the impact }\end{array}$ & $\begin{array}{l}\text { The subjective } \\
\text { dimension of tourism } \\
\text { impacts on host- } \\
\text { children has been } \\
\text { neglected. }\end{array}$ & $\begin{array}{l}\text { Future researchers are encouraged to } \\
\text { explore host-children's perception of } \\
\text { tourism on their lives, with specific } \\
\text { attention given to their subjective } \\
\text { wellbeing. }\end{array}$ \\
\hline
\end{tabular}


of modernisation driven by tourism on host-children's health. On the other hand, limited attention has been paid to the subjective dimension of tourism impacts, such as hostchildren's satisfaction with tourism impacts on their lives.

\section{Children's Involvement:}

Due to sensitivity, methodological and ethical challenges, limited studies have empirically explored host-children (in particular, child labourers). Within the limited empirical studies, far fewer studies have reflected children's voices.
Host-children need to engage in research with child-centred research methods.
Future research is encouraged to adopt a visual method triangulated with multiqualitative methods. 


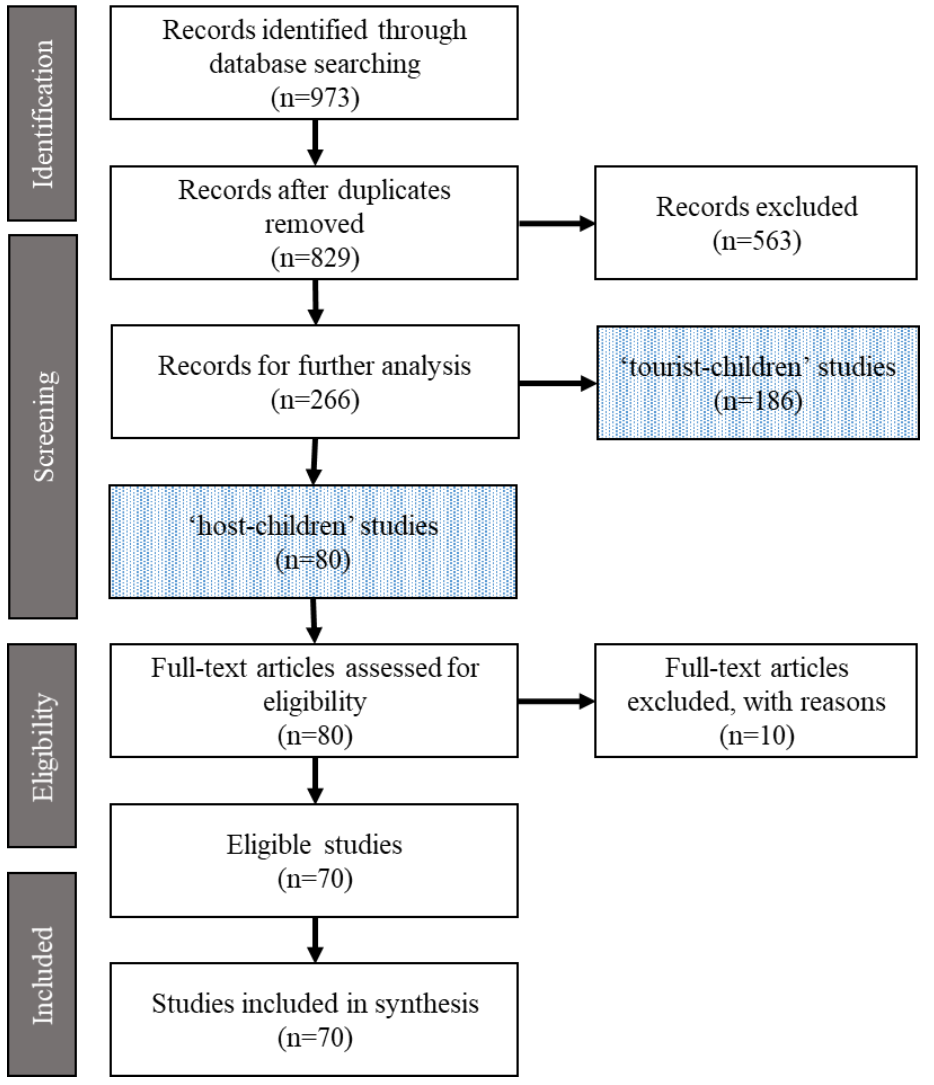

Fig 1. Modified PRISMA Flowchart

Source: Adapted from Moher et al. (2009)

Note. The shaded boxes are an additional step to the original PRISMA flowchart to identify the extent to which the existing literature paid attention to host-children compared with tourist-children. 


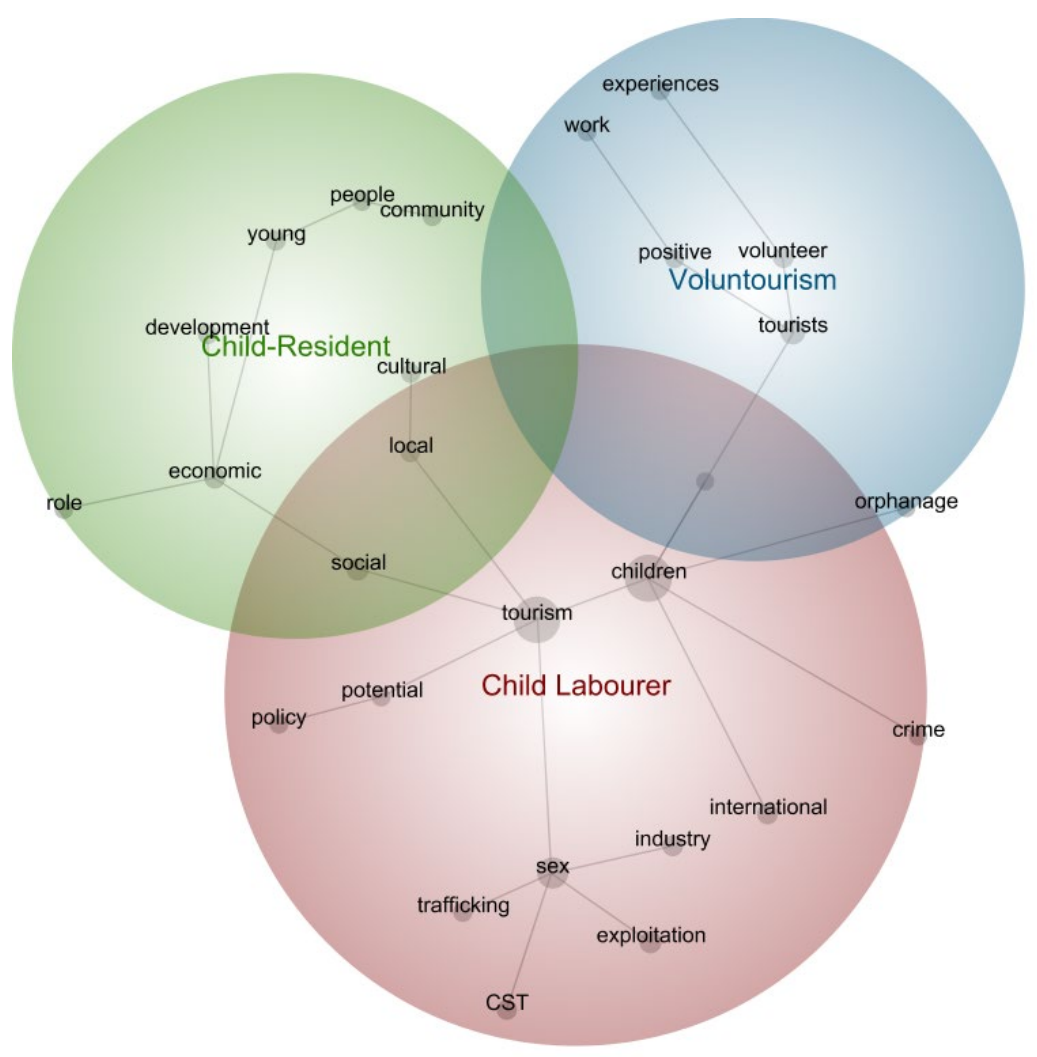

Fig 2.

Conceptual Map of Studies on Host-Children

Note. The themes and concepts in the conceptual map are machine-generated based on text frequency and word connection analysis. CST stands for Child Sex Tourism 


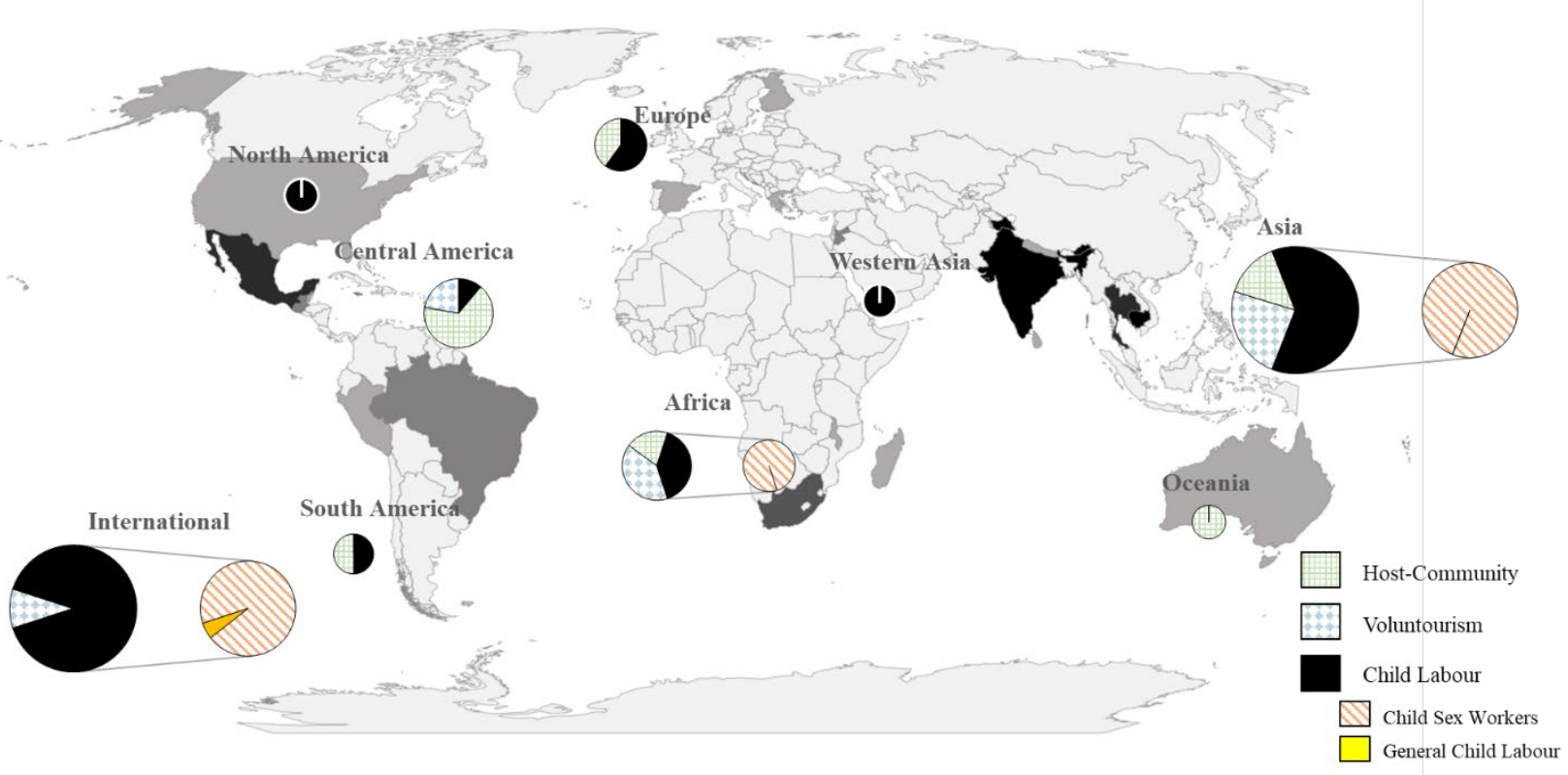

Fig3.

Geographical Distribution of Host Countries of 70 studies 


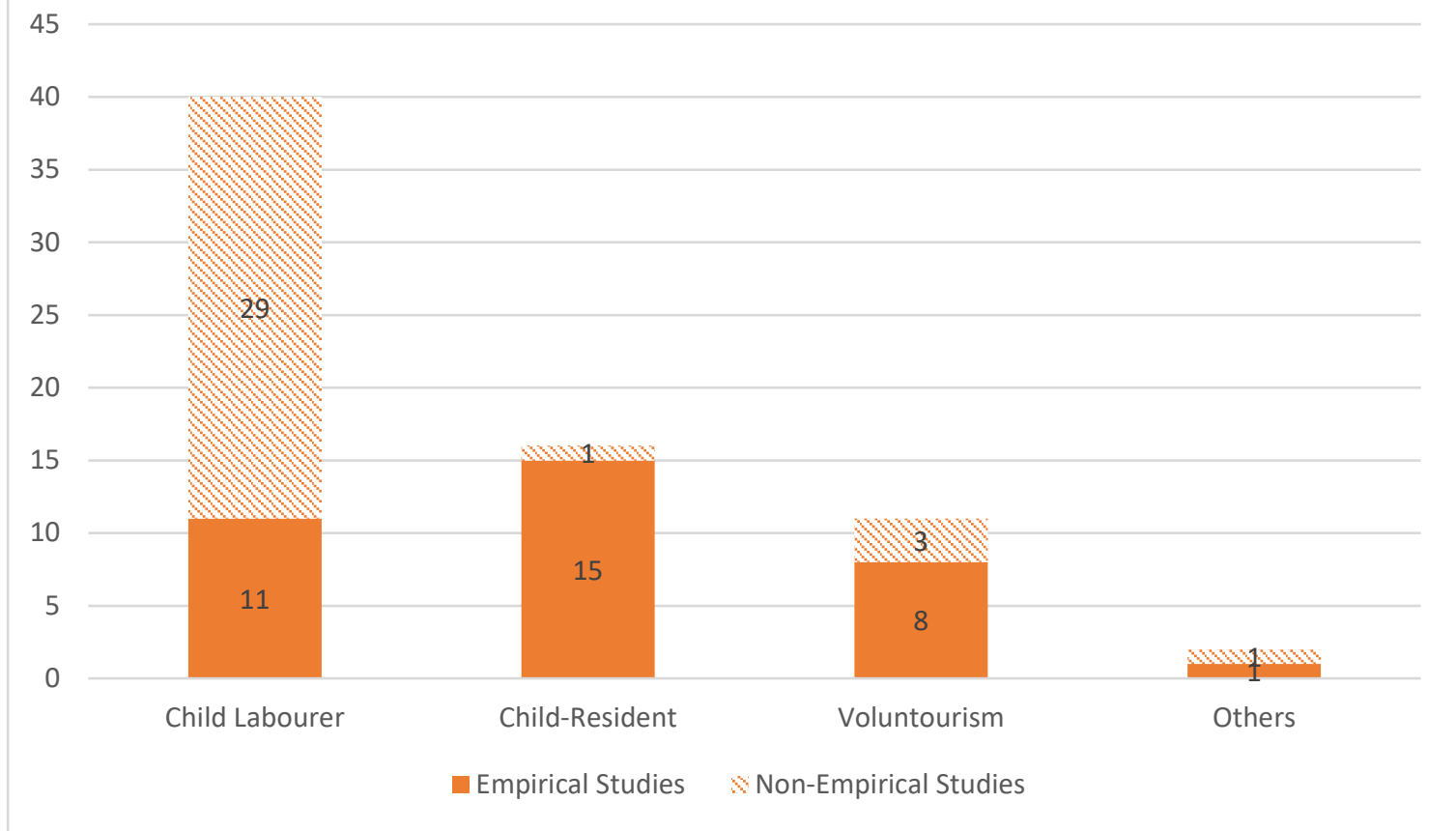

Fig 4.

Empirical Studies in Each Theme 